\title{
POLITICS OF THE DOMICILE IN THIONG'O'S MATIGARI
}

\author{
Sourav Kumar Nag
}

Onda Thana Mahavidyalaya, Bankura University

\begin{abstract}
My paper offers a reading of Ngugi Wa Thiong'o's Matigari (1989) and investigates the use of the home space as a site of protest. It is the home space that Matigari struggles to retrieve in the novel. The journeys undertaken by Matigari are metaphorically interwoven with his journeys within-the journeys in the realm of memory. In Matigari (1989), Matigari's search for a home space in the aftermath of the independence of an anonymous nation (identified as Kenya) culminates in the grim discovery of the neocolonial oppression that marks the collapse of the nationalist dreams. Hence, my main aim in this paper is to analyse the journeys undertaken by the characters in the novel, and in doing so, I will also try to explain the spatial politics that define these journeys.
\end{abstract}

Keywords: Neocolonialism, Space, Resistance, Home space, Memory, Ideology. 
I hope the running themes in the present collection will raise questions and promote debate about our present predicament. For we are all involved in a common problem: how best to build a true communal home for all Africans. Then all the black people, all the African masses can truthfully say: we have come home.

(Thiong'o, 1981, p. xix)

And so today is my homecoming and I want to bring my family together.

(Thiong'o, 1987, p. 22)

Postcolonial writers often use journeys as an important spatial trope for critiquing the colonial appropriation of space. In many postcolonial novels journey in search of the homeland has been used. Matigari (1989) by Thiong'o is an example/ an illustration of it. Matigari's journey in search of the home space subverts the colonial ethics of the domestic space as a stable, clean and tabular entity (Upstone, 2009. p. 117). In the novel, Thiong'o critiques the colonial appropriation of the home space that underlines the need of the white subjects to be located in a clean, comfortable and hygienic homestead in a colony away from the homestead of the natives in the marginal territories. The politics of the home space allegorises the formation of the nation. The colonial politics of the domestic space is revived in the neocolonial context. The primary focus of this paper is Thiong'o's critique of the neocolonial ethics of domesticity in Matigari (1989). Matigari travels within an anonymous nation (evidently Kenya) in search of the indigenous home space but discovers the marks of woe instead of the promised land of peace and harmony. Evidently, Matigari's dystopian findings question the validity of the neocolonial fashioning of domesticity in postindependence Kenya.

Home in the colonial literature has been represented as an 'idealized and apolitical location' (Upstone 115). The home as a personal space free from external politics is often associated with European domesticity. In White Man's Country: Lord Delamere and the making of Kenya, Elspeth Huxley (1956) glorifies the cause of the British settlers in Kenya in unequivocal terms and politicizes the history of brutal imperialism 'as a story of white masculinity and its pioneering adventure in bringing untouched land under cultivation and untamed people under British rule' and calls Jomo Kenyatta 'a small scale African Hitler' (147).
The colonial domestic spaces have been represented as 'white civilization' (p. 147) and the native Kenyans as outposts looming violent threats in forms of Mau Mau. Alison Blunt and Robyn Dowling (2006) allude to two popular photographs representing home in contrary ways. The first is 'The Sinews of Old England' by George Elgar Hicks, which represents the 'gendered spaces of home and nation' (p. 140); a married couple standing on the threshold of their house. The man with his muscular embodiment represents manhood as well as the English nation whereas the woman is portrayed as the symbol of domesticity. Another picture is entitled 'How the Mutiny came to English homes' shows the European domestic space as a site of fear and violent disruption of the peace and security represented by the former (p. 140). Significantly, both the paintings depict the idea of the symbolic significance of the home as a microcosmic nation space:

Nations are frequently figured through the iconography of familial and domestic space. The term 'nation' derives from 'natio': to be born. We speak of nations as 'motherlands' and 'fatherlands.' Foreigners 'adopt' countries that are not their native homes, and are 'naturalized' into the national family. We talk of the Family of Nations, of 'homelands' and 'native' lands.

(McClintock, 1995, p. 357)

In the English colonies, the home space followed the illusory Victorian ideals of domesticity. The division of the colonies into territories is a large-scale phenomenon of the division of the home space. The colonial civil planning marked the watertight division between the indigenous and the British settlement. The colonial home space was stuffed with the emergent middle-class values such as monogamy ('clean' sex, which has value), industrial capital ('clean' money, which has value), Christianity ('being washed in the blood of the lamb'), class control ('cleansing the great unwashed') and the imperial civilizing mission ('washing and clothing the savage') (Upstone, 2009, p. 116-7). With the newly constructed colonial domestic space, the naturalness of the imperial nation-building was justified. (McClintock, 1995, p. 208). The neo-colonial agencies validate and promote the construction of the nation's space on the former values of domesticity. The rapid urbanization, the various welfare movements and different cultural promotions in favour of a happy homestead in the post colony reinstate the colonial values of home space. Kaplan asserts that the term 'domestic' has 
a double meaning. It refers to both the space of the nation and the space of the household. These two meaning are intimately bound up with shifting ideas about the 'foreign:' 'Terms such as 'foreign' and 'domestic' are not neutral, but are rather 'heavily weighted metaphors imbued with racialized and gendered associations of home and family, outsiders and insiders, subjects and citizens' (Blunt \&Dowling, 2006, p. 143). We must remember that etymologically the verb form of the word 'domestic' is 'domesticate' which means to 'dominate' as well as to 'civilize' (McClintock, 1995, p. 35). Therefore, the home space in the colonial imagination was a localised site for domination and control that reflect the broader spectrum of the colonial subordination:

Through the rituals of domesticity, increasingly global and more often than not violent, animals, women and colonized peoples were wrested from their putatively 'natural' yet, ironically, 'unreasonable' state of savagery' and inducted through the domestic progress narrative into a hierarchical relation to white men.

(McClintock, 1995, p. 35)

Historically speaking, colonial notions of clean home spaces influenced the spatial demarcation of colonial Kenya. The British homestead in Kenya was represented as hygienic, stable and orderly; whereas those outside the colonial home space were represented as uncivilised and barbaric. The Mau Mau warriors, who inhabited forests, were the bestial and primordial forces in the colonial imagination. Only the docile Gikuyu subjects were given a clean and domestic status (Nicholls, 2010, p. 63). They were allowed to remain in the domestic spaces. The prisoners were categorized as 'black' (hardcore), 'grey' (Mau Mau supporters), and 'white' (clear and loyal). In Hola detention camp 11 Kenyan prisoners were beaten to death for refusing to work (Nicholls, 2010 , p. 64). The colonial government adopted some crucial military strategies to wipe out the Mau Mau supporters and workers.

Operation Anvil was one of the many military strategies of that kind. The Operation Anvil was shouldered in Nairobi in 1954 by 25000 men of the government's forces to find the Mau Mau supporters. (Nicholls, 2010, p. 64). The Villagization programme was initiated to relocate Gikuyu civilians to 'safe' villages that were surrounded by barbed wire so that the villagers might be alienated from the Mau Mau rebels (Nicholls, 2010, p. 66). In doing so, the
British Government was following the Old England model in the demarcation of the domestic space in Kenya. More than 25000 people were removed from their homes. The villagized settlements resulted in a model of domesticity founded on the ethics of division (Nicholls, 2010, p. 65-6).

In Matigari, Thiong'o critiqued the so-called welfare movements that do nothing other than adjusting and appropriating the neocolonial mechanism. The 'Housewives' Programme' broadcast on the radio is such a process. Like the 'Voice of Truth,' 'Housewives' Programme' creates a neocolonial socio-sexual space:

... This is the Voice of Truth. Next on the air is the Housewives' Programme. We shall be talking about family matters today ... The annual general meeting of the Women's Development Association was opened by the wife of the Minister for Truth and Justice yesterday. Madam the minister's wife, addressing the women, told them that adultery and drunkenness were the principal evils behind the destruction of many homes in the country. Madam the minister's wife urged all women to take refuge in the safety of the church and to stop competing with their husbands in drinking and adultery. Women were the corner-stones of the home, she said.

(Thiong'o, 1987, p. 09)

The socio-sexual institutions such as prostitution, nuclear family, polygamy, etc. were politicized and monitored by the neocolonial powers. The 'Housewives' Programme' on the radio is a neocolonial aural panopticon to modify and construct the socio-sexual institutions. The voice of sympathy and goodwill is a façade of neocolonial hegemony to control those institutions. Interestingly, colonization was politicized as a civilising mission rooted in the eastward journeys. Paradoxically, the neocolonial politicization of the civilizing missions is founded on the spaces of domesticity. The stabilization of the home space was at the heart of those missions.

Thiong'o in Matigari (1989) highlights the nationalist dream of returning to the pre-colonial home space. Matigari's dream represents the dream of thousands of Kenyans who fought for their independence. Matigari's dream of returning to the pre-colonial home disrupts the colonial ordering of the home space. The novel dramatizes the Mau Mau insurgency in a new format. Ngugi wrote Matigari (1989) largely in exile in London in the year 1983. In the novel, Ngugi 
adopted an oral storytelling mode. Incidentally, the Gikuyu word 'Matigari' means 'the patriots who have survived the bullets.' In the novel, Ngugi takes resort to Fanon's argument that decolonisation marks the meeting of the two forces--the colonising and the colonized and that the colonial rule was sustained with violence and repression. Decolonisation, according to Fanon, can only succeed by taking resort to violence (Fanon, 1965, p. 02). The publication of the novel created such unrest that the ruling government of Kenya immediately banned the novel. In the prefatory section of Matigari (1989), Ngugi has deliberately blurred the spatial and temporal specificity of action:

The country is imaginary - it has no name even. Reader/listener: may the story take place in the country of your choice!

The story has no fixed time.

Yesterday, the day before yesterday, last week ...

Last year ...

Or ten years ago?

Reader/listener: may the action take place in the time of your choice!

(Thiong'o, 1987, p. ix).

Thiong'o's postcolonial vision is not tied to Kenya only. The marks of capitalist oppression and exploitation discovered by Matigari are embossed on the forehead of every postcolony. Thiong'o portrays the post-independent crises and the failure of nationalism in an unequivocal tone. The colonial myth of the domestic space as a well settled, rooted and clean entity is violently subverted and challenged by the novelist. Matigari's disillusionment with the Uhuru and nationalist dreams for sweet homecoming culminates in his final resort to violence. At the very beginning of the novel, Matigari comes out of the forest with the conviction that the pre-colonial domestic harmony and peace have been restored after the Uhuru or Independence of Kenya. He comes under a huge Mugamo or a fig tree, 'right in the middle of a cluster of other trees. It was remarkable for its very wide trunk, and its four roots were visible, with one jutting out from the middle, and three others sticking out at the sides' (Thiong'o, 1987, p. 4). The Mugamo tree in Mattagami (1989) is a mighty symbol of the succession of the colonial rule in Kenya in a new format, say neocolonialism. According to the prophecy of Mugo, a Gikuyu sage, the fall of a Mugamo tree in Kenya signals the end of the colonial rule.
Mugamo trees are deemed holy by the Kenyans. However, the huge Mugamo tree under which Matigari stands symbolically subverts his hope of the pre-colonial restoration of the home space. However, Matigari remains ignorant of the omen and silently buries his rifle, sword and a cartridge belt wrapped in a plastic cover. The silent burial of the arms ironically emblematises Matigari's utopian dream that arms are no more needed:

'He tore a strip of bark from a tree and girded himself with it, once again murmuring, ' Instead, I have now girded myself with a belt of peace, I shall go back to my house and rebuild my home' (Thiong'o, 1987, p. 5).

As already said, Matigari's dream of house space is intimately woven with his dream of the home space that is the space of domicile:

'I will call together all the members of the family and tell them: Let's go home and light the fire together. Let us rebuild our home. The wise among them will understand the hint." (Thiong'o, 1987, p. 24).

In the novel, Matigari's search for the home and his failure to find the same underline the failure of the nationalist dream of liberty. Incidentally, Matigari, as Gikandi (2002) suggests, can be divided into three parts. The first part consists of Matigari's journey as a quest for personal experience of the postcolony.

The second part deals with his moral and ethical values such as truth and justice and the final part deals with his disillusionment (Thiong'o, 1987, $p$. 241-2). The first part dealing with Matigari's quest for the home space is, in the words of Gikandi, marked by a temporal dimension:

'Matigari's journey is one in which the temporal dimension (the hero's return) is defined by a degree of risk. Displaced from the real experience in the postcolony, Matigari has to depend on others for his education in the ways of the new world' (Thiong'o, 1987, p. 242).

Contrary to Gikandi's claim, I find that the journey Matigari undertakes in the first part of the novel is a postcolonial re-play of the colonial journey defined in a magical-realist dimension. Matigari's journey is a violent disruption of the linear temporality. Matigari's self-knowledge of the postcolony is a colluded fiction-- a utopia that is violently topsy-turvied when 
he encounters Muriuki, Ngaruro, and Guthera. The discursive dislocation results in Matigari's dystopian realization that the post-independent world is a neocolonial world in which Settler Williams continues to thrive. Matigari's search for the pre-colonial home space is intrinsically wrought with his dream of a family, the space of the house becoming a utopian longing for the space of a home.

The second part of the novel, as Gikandi (2002) observes, deals with Matigari's search for 'moral or ethical values' (p. 243). According to Gikandi the graph of teaching and learning is reversed in the second section of the novel. The character of Matigari possesses a doubleness that is he is at once the same time the present and the past. He is not only a character in the novel but a phenomenon. In the first part, he learns the dystopian lesson of the neocolonial exploitation which underpins his postcolonial hope of liberty. In the second part of the novel, it is Matigari who teaches the lessons of ethicality and morality. Matigari produces a new doctrine of truthfulness and humanitarianism to counter the hollow colonial ethics of governance. He travels around the country to ask people where he could find truth and justice. Thus, he makes these values 'central to nation and identity' (Gikandi. 2002, p. 244). Matigari's travels, thus, displace the neocolonial fabrication of stable and civilized space and replaces these with a revival of old values that is the doctrines of truth and justice. Moreover, Matigari as a character transcends its fictional boundaries and becomes an element of storytelling: 'On the contrary, the more people become absorbed in Matigari's fiction, the more it becomes an indispensable counterpoint to official discourse; in being able to talk about the phenomenon of the strange man seeking truth and justice, the populace is able to overcome the culture of silence sanctioned by the state' (Gikandi, 2002, p. 244). He becomes a part of the regional narrative that actively challenges the neocolonial domination. The monopoly of the national discourse fabricated for the smooth functioning of the neocolonial hegemony is severely challenged by Matigari. The alternative discourse of morality, truth, and justice crosses the threshold of the pages of Ngugi's novel and becomes a national phenomenon.

The last part of the novel deals with Matigari's disenchantment with the nationalist movements and his return to the armed struggle. The neocolonial threats disillusion him and he learns the lesson that the dream of national freedom is a mere utopia. But
Matigari's return to the armed struggle is tinged with grains of doubt. Matigari's dream of homecoming is not personal. It is related to the nationalist concept of Motherland. He realizes that he cannot return home alone:

His thoughts took flight. How can I return home all alone? How can I cross the threshold of my house all alone? What makes a home? It is the men, women and children - the entire family. I must rise up now and go to all the public places, blowing the horn of patriotic service and the trumpet of patriotic victory, and call up my -people - my parents, my wives, my children. We shall all gather, go home together, light the fire together and build our home together. Those who eat alone, die alone. Could I have forgotten so soon the song we used to sing?'

(Thiong'o, 1987, p. 06).

Evidently, in the novel, Ngugi uses home space as a metaphor for the nation. Home does not refer to a personal and enclosed site away from the public sphere or as an interiorised entity of but as a pluralistic space that at once undermines the imperial ethics of domestic hygiene and luxury. Ngugi's concept of home is intimately associated with the nationalist concept of home as a spatial metaphor for the nation. The home space in the nationalist imagination was a reactionary space of resistance and return:

In anti-imperial nationalist politics, the home and the nation were imagined in ways that resisted rather than repeated westernization. As Chatterjee argues, nationalist visions of home and nation were embodied by Bengali women and their domestic roles, which were fashioned as distinct not only from the stereotypical British memsahib but also from Anglo-Indian women.

(Blunt, 2005, p. 30)

Matigari's call for returning to the home is metaphorically layered with his nationalistic dreams of retrieving the pre-colonial culture in the aftermath of independence:

Let's go home and light the fire together. Let us rebuild our home. The wise among them will understand the hint' (Thiong'o, 1987, p. 24).

However, Matigari's search for the domestic space is undermined by the 'Voice of Truth'-- the voice of the bourgeoisie government in Kenya. In the novel, the 'Voice of Truth' functions like an aural 'panopticon' 
that operates invisibly and charters out the ways of the citizens.

Home and homecoming become the chief motif of the novel and the possibility of homecoming is deferred eternally to suggest the impossibility of the nationalist negotiation. Ngugi is evidently rebuilding his dream of real independence on a symbolic aspect -- with the deconstruction of the colonial myths of home. At the same time, Ngugi advocates the restoration of pre-colonial home space that consists of the indigenous culture of the present postcolony. Ngugi's call for Pan-Africanism is firmly rooted in his vision of home and homecoming.

It is interesting to note that Matigari's concept of home is built upon the notion of family, especially the children and women. Therefore, the concept of home in the novel is not merely an imaginary geographical but a cultural entity that rests on the primitive notions of love, togetherness and selflessness. Matigari's dream of sweet homecoming is challenged when he looks at the children in the garbage heaps of a leather factory. In the novel entitled the 'Anglo-American Leather and Plastic Works', the industry represents the core of capitalist exploitation in the country. The garbage heap symbolises the deposit of the harm that the neocolonial government has dumped:

He did not even talk to the guard. He quickened his pace and followed the children and the tractor. His heart beat wildly. Let me hurry and tell them that I'm back. Let me tell them that the years of roaming and wandering are over. We shall all go home together. We shall enter the house together. We shall light the fire together. After all, the struggle was for the house, wasn't it?

A home... a shelter... with children playing on the veranda or in the open air ... sharing what little we have... Joy after all that suffering... cold... hunger... nakedness... sleeping nights...fatigue... And how often did we come close to death? Victory is born of struggle. There is no night so long that it does not end with dawn.

(Thiong'o, 1987, p. 10-1)

However, the rapid deterioration of the children's space in the neo-colonial context marks the failure of Matigari's nationalist ideologies and his utopian dream of postcolonial homecoming. The disruption of the home space in the neocolonial context is initially reflected in the sufferings of the street children in the novel. The children's space in Matigari (1989) is located on the macadam on which they fight for any offal. Their childhood space is ravished by the colonial urbanized spaces. Matigari's vision of the promised space after independence is subverted by what he sees. He encounters the children standing in a queue to pay a fee to enter an enclosed ground where heaps of rubbish are dumped.

The children pay to enable themselves 'to fight it out with dogs, vultures, rats, all sorts of scavengers and vermin, for pieces of string, patches of cloth, odd bits of leather, shoe soles, rubber bands, threads, rotten tomatoes, sugarcane chaff, banana peels, bones ... anything!' (Thiong'o, 1987, p.11).

This grim reality brings him to his senses. He sees two policemen with a dog, a tractor driver, and the two men at the gate jingling the money they had collected and shared it among themselves. Matigari tries to visualise his home:

'A vision of his house appeared before him. He had not been there, he had not yet been home' (Thiong'o, 1987, p.12).

The urge to go and look at his house seized him with the force of thirst and hunger for many days.

Another important trope used by Ngugi is that of homelessness. The homestead of Settler William is pitted against Matigari's homelessness. Matigari's search for the home space reinforces the fact that he is homeless. Matigari's spatial bankruptcy marks the presence of spatial chaos that subverts the neocolonial perception of space as fixed and organised:

You see I built the house with my own hands. But Settler Williams slept in it and I would sleep inside on the veranda. I tended the estates that spread around the house for miles. But it was Settler Williams who took home the harvest. I was left to pick thinking he might have left behind. I worked all the machines and in all the industries, but it was Settler Williams who would take the profits to the bank and I would end up with the cent that he flung my way. I am sure that you already know all this. I produced everything on that farm with my own labour. But all the gains went to Settler Williams. What a world!

(Thiong'o, 1987, p. 21)

But the subversion of the neocolonial ethics of the home space is not altogether materialized. Matigari 
recalled how his attempt to kill Williams was thwarted by John Boy, a 'black man' and Williams' servant who jumped on his back 'screaming:'

Under the colonial system, a middle class which accumulates capital is an impossible phenomenon. Now, precisely, it would seem that the historical vocation of an authentic national middle class in an underdeveloped country is to repudiate its own nature in so far it as it is bourgeois, that is to say in so far as it is the tool of capitalism, and to make itself the willing slave of that revolutionary capital which is the people.

(Fanon, 1965, p. 149)

The deaths of Williams and John Boy consoled Matigari and seemed to fulfil his dream of the free national space. But the death of Settler Williams did not root out the suffering of the colonized. Ngariro reminded Matigari that one of the company directors was Williams and his deputy was John Boy:

'Just a moment,' Ngariro said, as a new thought struck him. 'Williams? Boy? One of the company directors is called Williams. Robert Williams. His deputy is called John Boy' (Thiong'o, 1987, p. 24).

At the end of the novel, Matigari and Guthera dive into the river to escape being captured by the policemen. All of a sudden, the sky roared and the lightning flashed. The rain started to fall. Matigari's failure to get his home space back is surpassed by a romantic vision of the revolution and violence:

Finally, he picked up the AK 47 and slung it over his shoulder. He stood for a while under the mugumo tree. And then he heard the sound of hoofs nearby. His heart skipped a beat. But it was only a riderless horse.... Muriuki watched the rain as it fell. His glance swept the banks along which he stood. He looked across the river and beyond to the other valleys, other ridges and other mountains. Far, far away, he heard the distant sound of the siren as it called out to all the workers. He recalled the night of the workers' strike. And suddenly he seemed to hear the workers' voices, the voices of the peasants, the voices of the students and of other patriots of all the different nationalities of the land, singing in harmony:

Victory shall be ours!

Victory shall be ours!

Victory shall be ours!

Victory shall be ours!
To conclude, therefore, it may be stated that in Matigari (1989), Ngugi critiques the neocolonial appropriation of the home space. Ngugi's primary concern in the novel is to discover the inherent chaos in the neocolonial project. Matigari's search for the home space for his fellow nationals and the failure of the same underline the 'pitfalls of national consciousness' (Fanon) as well.

The neocolonial mechanisms implemented by the Kenyan bourgeoisie perpetuate the capitalist exploitation even after independence. In the novel, Ngugi focuses on the colonial ethics of home space. Matigari's journeys subvert the ethics of the home space as a fixed, disciplined and hygienic locale. The homelessness of the natives, the suffering of the children and other discernible marks of the woe discovered by Matigari underline the inherent chaos in the capitalist edifice of the neocolonial welfare projects. Ngugi in the novel takes resort to a dystopian vision for challenging the neocolonial utopianism imported from Europe.

At the same time, Matigari's dream for building a home for all the natives underlines postcolonial utopianism though it is true and honest in its essence.

Unlike the feigned neocolonial utopias that are built upon the dishonest political economy, feigned welfare projects and capitalist power play, the postcolonial utopianism borders on a true longing for the cultural homecoming.

It should also be noted that Ngugi's postcolonial utopianism is both spatial and temporal. His advocacy of the cultural homecoming incorporates nostalgia, spatial reconstruction of the indigenous home space and memory.

\section{Note:}

Settler Williams in Matigari (1989) was Robert Williams, one of the white settlers in the fictitious town in Matigari (1989). He is a British predator who with his deputy John Boy extorted the lands of the natives.

(Thiong'o, 1987, p. 175). 


\section{References}

»Blunt A. (2005). Domicile and diaspora: Anglo-Indian women and the spatial politics of home. Oxford: Blackwell.

» Blunt, A. (2005), \& Dowling, R. M. (2006). Home. New York: Routledge.

»Clintock, A. M. (1995). Imperial Leather: Race, Gender, and Sexuality in the Colonial Conquest. New York: Routledge.

» Fanon, F. (1965). The Wretched of the Earth ... (C. Farrington, Trans.). New York: Grove Press.

» Gikandi, S. (2002). Ngugi wa Thiongo. Cambridge: Cambridge Univ. Press.

» Huxley, E. (1956). White Man's Country: Lord Delamere and the Making of Kenya. London: Chatto \& Windus.

» Nicholls, B. (2010). Ngugi Wa Thiong'o, Gender, and the Ethics Of Postcolonial Reading. England: Ashgate.

» Wa Thiong'o, N. (2002). A Grain of Wheat. London: Penguin Books.

»Wa Thiong'o, N. (1981). Homecoming. London: Heinemann.

$»$ Wa Thiong'o, N. (1987). Matigari. USA: Heinemann.

»Upstone, S. (2009). Spatial Politics in the Postcolonial Novel. Farnham: Ashgate.

» Webster, W. (1998). Imagining home: Gender, 'Race,' and National Identity, 1945-64. London: UCL Press 